\title{
Effects of Fiscal Policy under Different Capital Mobility
}

\author{
Ping $\operatorname{Han}^{1}$ \\ ${ }^{1}$ School of Economics and Finance, Shandong Jiaotong University, Jinan, Shandong, China \\ Correspondence: Ping Han, School of Economics and Finance, Shandong Jiaotong University, Jinan, Shandong, \\ China. E-mail: vhanping@126.com \\ Received: January 14, 2014 \\ Accepted: February 16, 2014 \\ Online Published: February 19, 2014 \\ doi:10.5430/afr.v3n1p111 \\ URL: http://dx.doi.org/10.5430/afr.v3n1p111
}

\begin{abstract}
Mundell-Fleming model is a standard open macroeconomic theory that tries to describe the effects of fiscal and monetary policies. It is believed that, under assumptions of small country and perfect capital mobility, fiscal policy is strong under fixed exchange rate while monetary policy is strong under floating exchange rate. This article extends assumptions of this theory, discusses effects of fiscal policy in a big, open economy under different capital mobility situations.
\end{abstract}

Keywords: Mundell-Fleming Model, International capital mobility, Fixed exchange rate, Floating exchange rate

\section{Introduction}

In this paper we extends assumption of Mundell-Fleming model from a small country under perfect capital mobility to a big country under different capital mobility, reveals the effects of fiscal policy under different capital mobility situations which is very different from Mundell-Fleming Model.

\subsection{Basic theory}

In 1963, Prof. Robert Mundell wrote a paper by working with Marcus Fleming, which gave birth to Mundell-Fleming model. It is an open macro application of the standard IS-LM analysis which considers three aspects of macro economy: (1) domestic product market equilibrium (IS curve); (2) money market equilibrium (LM curve); (3) foreign exchange market equilibrium (FE curve).

The domestic product market is in equilibrium when

$$
\stackrel{+}{\mathrm{S}}(\mathrm{Y})=\mathrm{I}_{\mathrm{d}}(\mathrm{i})+\mathrm{X}-\mathrm{M}(\mathrm{Y})
$$

Here the signs above the equation indicate the direction of each influence in parentheses on the value of the variable it affects. From equation (1), the domestic product market equilibrium can be pictured as the "IS curve" of figure 1. The IS curve shows all possible combinations of the interest and real GDP Y that are consistent with equilibrium in the goods and services sector of the national economy, given the state of other fundamental influences. If any of these other fundamental influences change, the entire IS curve shifts. The exogenous shocks that shift the IS curve include: (1) expansionary or contractionary fiscal policy; (2) exogenous increase or decrease in household consumption and domestic real investment; (3) an exogenous increase or decrease in exports and imports.

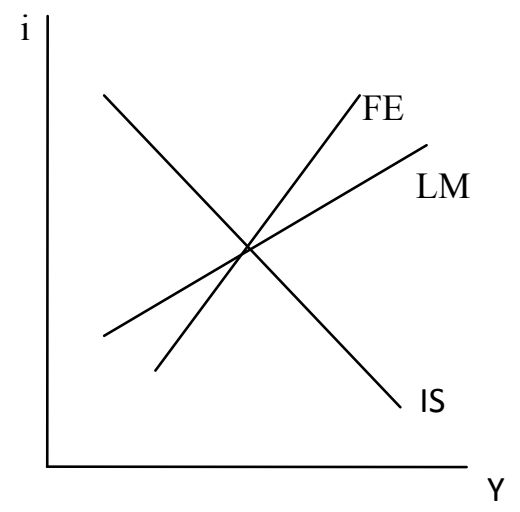

Figure 1. The equilibrium situation of three markets together 
In money market, there is a balancing of supply and demand. The demand for money $\mathrm{L}$ is positively related to nominal GDP and negatively related to the level of interest rates available on other financial assets:

$$
\mathrm{L}=\mathrm{L}(\mathrm{PY}, \mathrm{i})
$$

The equilibrium between money supply $\mathrm{M}^{\mathrm{s}}$ and money demands is then

$$
\begin{gathered}
+- \\
\mathrm{M}^{\mathrm{s}}=\mathrm{L}(\mathrm{PY}, \mathrm{i})
\end{gathered}
$$

The money market equilibrium can be pictured as the "LM curve" of figure1. It shows all possible combinations of interest rate $\mathrm{i}$ and real GDP Y that are consistent with equilibrium in the money sector of the national economy, given the state of other fundamental influences. If any of these other fundamental influences changes, then the entire LM curve changes. Factors that will shift the LM curve include: (1) expansionary or contractionary monetary policy; (2) increase or decrease in the country's average price level; (3) exogenous decrease or increase in money demand.

In the foreign exchange market, official settlement balance B equals the current account balance CA plus the capital account balance KA.

$$
\mathrm{B}=\stackrel{-}{-} \stackrel{+}{\mathrm{CA}}(\mathrm{Y})+\mathrm{KA}(\mathrm{i})
$$

FE curve in figure1 shows the sets of all interest-and-production combinations in a country that result in a zero value for its official settlements balance. If any of other fundamental influences changes, the entire FE curve shift. They include: (1) an exogenous increase or decrease in exports or imports. (2) Exogenous changes that result in an increase or decrease in capital flows (Pugel, 2008).

\subsection{Mundell-Fleming model}

Mundell-Fleming model believes that, under assumptions of small country and fully capital mobility, fiscal policy is strong under fixed exchange rate while monetary policy is strong under floating exchange rate.

If a country is in fully capital mobility, FE curve must be a flat one (figure 2), then

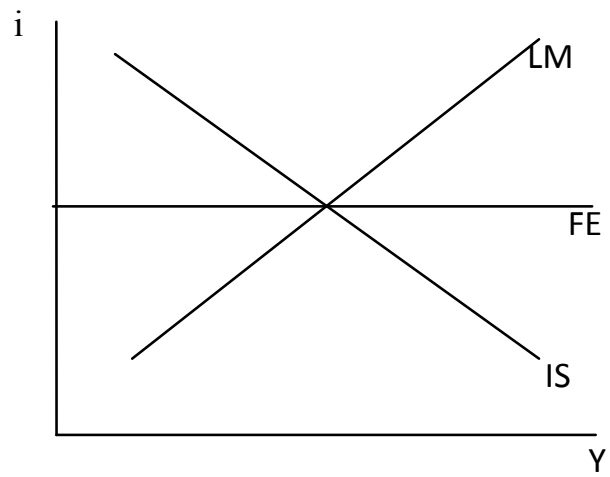

Figure 2. Fully capital mobility

(1) Under fixed exchange rate, expansionary tiscal policy shitts IS curve to right and the IS-LM intersection shifts from $\mathrm{E}$ to $\mathrm{K}$, the payment balance is surplus. In order to defend fixed exchange rate, central bank will sell domestic currency in foreign exchange market, which will cause LM curve move to right (figure3-1), and the economy shifts toward a new full equilibrium at point E'. Domestic production increased and fiscal policy is strong.

(2) Under fixed exchange rate, expansionary monetary policy shifts LM curve to right and the IS-LM intersection shifts from $\mathrm{E}$ to $\mathrm{K}$, the payment balance is deficit. In order to defend fixed exchange rate, central bank will buy domestic currency in foreign exchange market, which will cause LM curve move to left (figure3-2), and the economy shifts back to point $\mathrm{E}$. domestic production will not change and monetary policy is impotent.

(3) Under floating exchange rate, expansionary fiscal policy shifts IS curve to right and the IS-LM intersection shifts from $\mathrm{E}$ to $\mathrm{K}$, the payment balance is surplus. Domestic currency will appreciate which will decrease 
exports (figure4-1). IS curve move to left and the economy shifts back to point E. domestic production will not change and fiscal policy is impotent.

(4) Under floating exchange rate, expansionary monetary policy shifts LM curve to right and the IS-LM intersection shifts from $\mathrm{E}$ to $\mathrm{K}$, the payment balance is deficit. Domestic currency will depreciate which will cause exports increase (figure4-2). IS curve move to right and the economy shifts toward a new full equilibrium at point E'. Domestic production increased and monetary policy is strong (Mundell, 1962, 1963, 1964, 1968; Fleming, 1969).

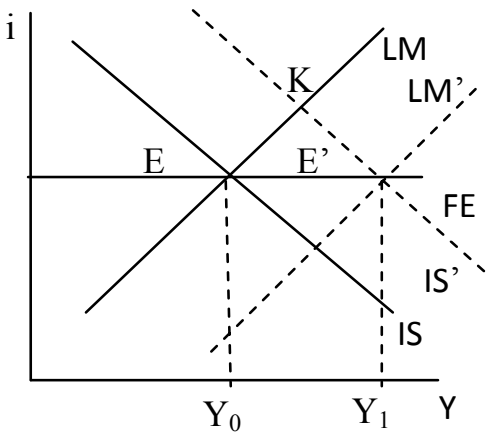

Figure 3-1.Fiscal policy is strong under fixed exchange rate

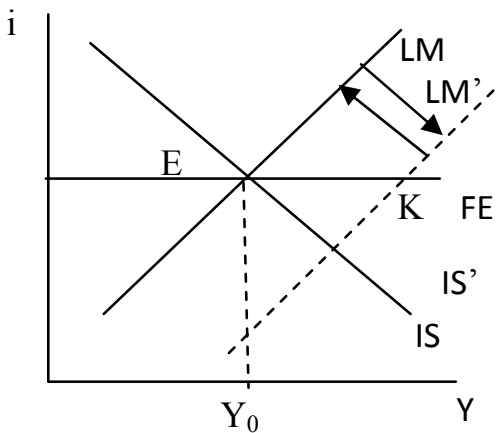

Figure 3-2. Monetary policy is impotent under fixed exchange rate

Figure 3. Fiscal and monetary policy under fixed exchange rate

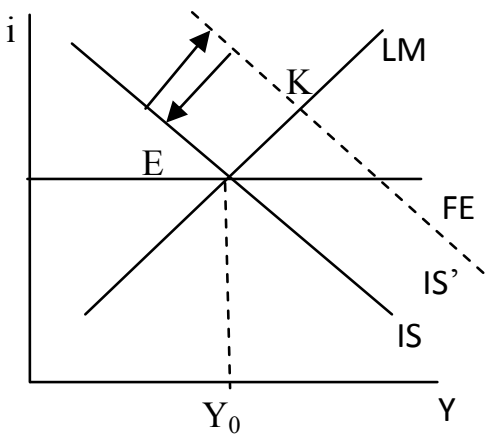

Figure 4-1. Fiscal policy is impotent under floating exchange rate

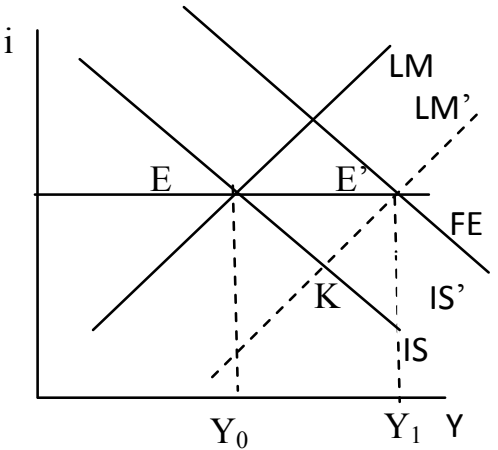

Figure 4-2. monetary policy is strong under fixed exchange rate

\section{Methods}

Figure 4. Fiscal and monetary policy under floating exchange rate

\subsection{Hypotheses}

Mundell-Fleming model suppose that it is in a small country and the country's capital is fully mobile. In practice, it is not often that a country's capital is fully mobile. Mostly it is imperfect mobility or sometimes it is immobility. Perfect mobility and immobility are two extreme cases. Imperfect mobility is a most likely case.

Here, we extend hypotheses of Mundell-Fleming model to a big country and discuss effects of fiscal policy under different capital mobilities. Then, we will have three kinds of capital mobility: (1) perfect mobility (we have discussed it in Mundell-Fleming model and will not concern below); (2) imperfect capital mobility (figure 5); (3) immobility (figure 6). 


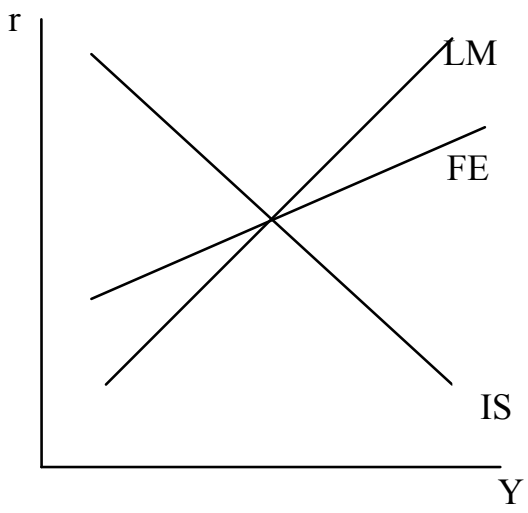

Figure 5. Imperfect capital mobility

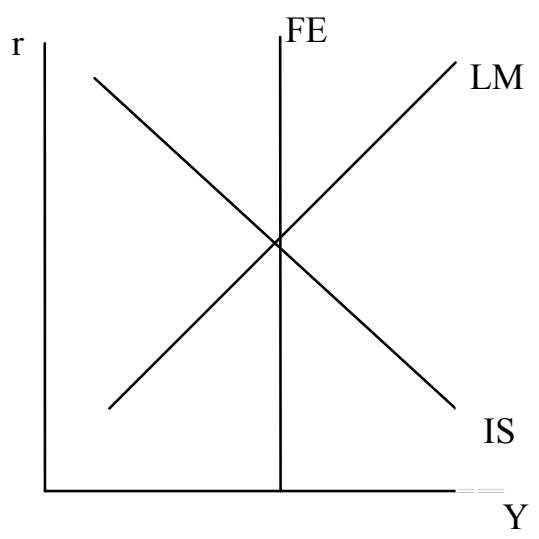

Figure 6. Capital immobility

\subsection{Analysis}

(1)Effects of fiscal policy under imperfect capital mobility

If a country is imperfect capital mobility, FE curve is upward, an expansionary fiscal policy will move IS curve to right. The new intersection of IS'-LM curve is to the left of FE curve which is a balance of payment surplus. Balance of payment surplus will cause domestic currency appreciate. Under a fixed exchange rate, government will intervene in foreign exchange market by buying foreign currency and sell domestic currency in order to prevent currency appreciation. The intervention will cause LM curve move to right. At last, the new intersection of IS-LM-FE is E', which is a higher domestic production compare with initial $\mathrm{E}$ (figure 7-1). So, under fixed exchange rate and imperfect capital mobility, fiscal policy is strong.

If it is a floating exchange rate, currency appreciation will not cause government intervention because floating exchange rate allows currency fluctuation. The appreciation will increase import and decrease export which will cause IS and FE curve move to left. The new intersection of IS-LM-FE is E' which is a higher production compare with initial E (figure 7-2). But the effect of fiscal policy under floating exchange rate is less strong than it is under fixed exchange rate.

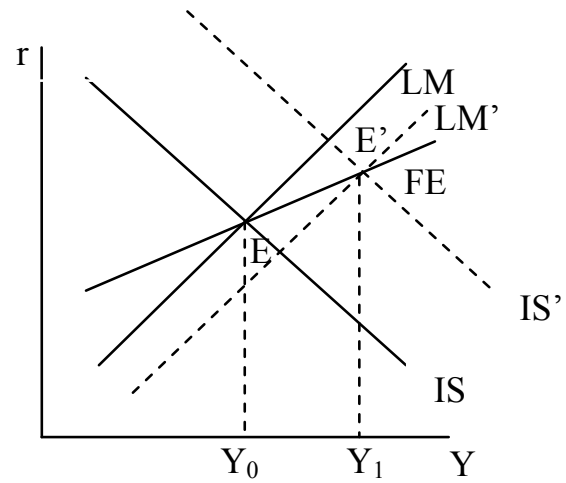

Figure 7-1 Fixed exchange rate

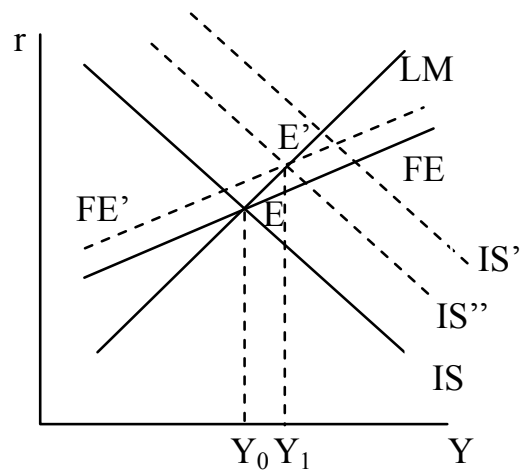

Figure 7-2 Floating exchange rate

Figure 7. Effects of fiscal policy under imperfect capital mobility

(2) Effects of fiscal policy under capital immobility

If a country is capital immobility, FE curve is vertical, an expansionary fiscal policy will move IS curve to right. The new intersection of IS'-LM curve is to the right of FE curve which is a balance of payment deficit. Balance of payment deficit will cause domestic currency depreciate. Under a fixed exchange rate, government will intervene in foreign exchange market by buying domestic currency and sell foreign currency in order to prevent currency depreciation. The intervention will cause LM curve move to left. At last, the new intersection of IS-LM-FE is E', 
which is the same domestic production compare with initial E (figure 8-1). So, under fixed exchange rate and capital immobility, fiscal policy is impotent.

If it is a floating exchange rate, currency depreciation will not cause government intervention because floating exchange rate allows currency fluctuation. The depreciation will decrease import and increase export which will cause IS and FE curve move to right. The new intersection of IS-LM-FE is E' which is a higher production compare with initial E (figure 8-2). Fiscal policy is extremely strong if the capital of this country is immobility.

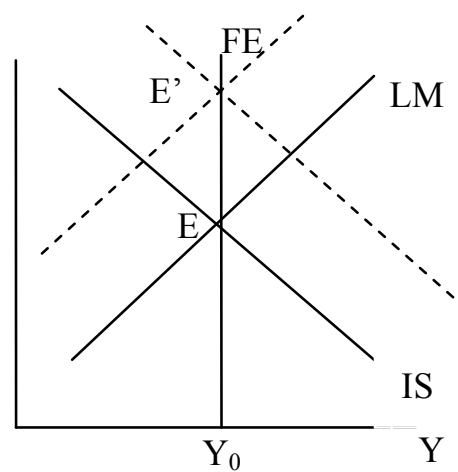

figure8-1 fixed exchange rate

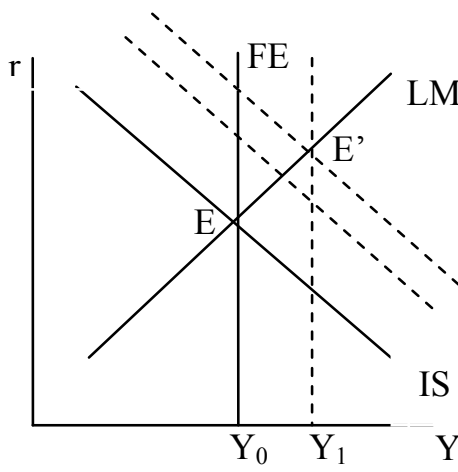

Figure 8-2 floating exchange rate

Figure 8. Effects of fiscal policy under capital immobility

\section{Conclusion and further work}

From the above analysis, we can see that Mundell-Fleming Model is not absolutely right. The effect of fiscal policy depends on capital mobility. If a country is perfect capital mobility, fiscal policy is strong under fixed exchange rate while it is impotent under floating exchange rate; If a country is imperfect capital mobility, fiscal policy is strong both under fixed and floating exchange rate; If it is capital immobility, fiscal policy is impotent under fixed exchange rate while it is strong under floating exchange rate (table 1).

Table 1. Effects of fiscal policy under different capital mobility

\begin{tabular}{lll}
\hline & Fixed exchange rate & Floating exchange rate \\
\hline Perfect capital mobility & Extremely strong & impotent \\
Imperfect capital mobility & strong & strong \\
Capital immobility & impotent & Extremely strong \\
\hline
\end{tabular}

In this article, we just discuss effect of fiscal policy under different capital mobility. We have known that Mundell-Fleming model is not absolutely right if we extend its hypothesis from perfect capital mobility to different capital mobility. In fact, effect of monetary policy is also not absolutely right if we do the same extension. Due to the limitation of this article, it will be discussed in further work.

\section{References}

Fleming, J. Marcus \& Richard N. (1969). International Finance. New York: Penguin Books.

J. Marcus Fleming \& Robert A. Mundell. (1964). Official Intervention on the Forward Exchange Market: A Simplified Analysis. IMF Staff Papers. New York: Palgrave Macmillan.

Robert A. Mundell. (1962). The Appropriate Use of Monetary and Fiscal Policy for Internal and External Stability. IMF Staff Papers. New York: Palgrave Macmillan, vol. 9(1), pages 70-79, March.

Robert A. Mundell. (1963). Capital mobility and stabilization policy under fixed and flexible exchange rates. Canadian Journal of Economic and Political Science. 29 (4): 475-485. http://dx.doi.org/10.2307/139336

Robert A. Mundell. (1963). Inflation and Real Interest. Journal of Political Economy, 71, University of Chicago Press, vol. 71, pages 280.

Robert A. Mundell. (1968). International Economics. New York: Macmillan.

Thomas A. Pugel. (2008). International Economics (14th edition). Boston: McGraw-Hill.

Young. Warren \& Sandy Darity. Jr. (2004). IS-LM-BP: An Inquest, History of Political Economy 36 (Suppl 1): 127-164, 2004. http://dx.doi.org/10.1215/00182702-36-Suppl_1-127 